\title{
LAS QUERELLAS DE LA PAZ: \\ PATRONATO REAL, PÚBLICO Y LITURGIA EN LA NUEVA ESPAÑA, 1750-1800
}

\author{
POR \\ DAVID CARBAJAL LÓPEZ \\ Universidad de Guadalajara-Centro Universitario de los Lagos \\ davidclopez@hotmail.com
}

\section{RESUMEN}

En el siglo XVI, la Reforma católica suprimió el beso de la paz entre los fieles en las ceremonias de la misa, estableciendo en cambio el beso del portapaz en las misas solemnes, reservado para clero, para los soberanos y sus magistrados. En el mundo hispánico y en particular en el reino de Nueva España durante la segunda mitad del siglo XVIII, el portapaz se convirtió por ello en motivo de querellas entre el clero, los magistrados y los miembros de los ayuntamientos. Mientras obispos y canónigos trataban de preservar lo que estimaban un elemento propio de ceremonias sagradas y distintivo de la jerarquía clerical, las autoridades civiles reclamaron su presentación fundados tanto en la regalía del Patronato regio de la Iglesia, como en motivos de utilidad del público.

PALABRAS CLAVE: Ceremonias, Real Patronato, Reformas borbónicas, Utilidad pública.

\section{THE COMPLAINTS OF THE PAX: ROYAL PATRONAGE, PUBLIC AND LITURGY IN NEW SPAIN, 1750-1800}

\begin{abstract}
In the 16th century, the Catholic Reformation abolished the kiss of peace among the faithful in the ceremonies of the Mass, establishing instead the Pax-board at solemn Masses, reserved for clergy, sovereign, and magistrates. In the Hispanic world, particularly in the realm of New Spain during the second half of the eighteenth century, Pax became a source of complaints among the clergy, judges, and members of local councils. While bishops and clergy were trying to preserve what they considered a separate and distinctive element of sacred ceremonies and distinctive characteristic of the clerical hierarchy, the civil authorities claimed its presentation based on Patronage on the Church, as well as reasons for public utility.
\end{abstract}

KEY WORDS: Ceremonies, Royal Patronage, Bourbon Reforms, Public Utility.

Recibido/Received 19-12-2014

Aceptado/Accepted 22-01-2016
"El beso, en las Sagradas Escrituras, significa ciertamente la unión, la caridad, la paz, el respeto", afirmaba el obispo Guillaume Durand en su Rational, escrito en el siglo XIII y durante largos siglos importante autoridad en materias litúrgicas. ${ }^{1}$ La explicación era parte de la disertación del obispo a propósito del significado místico de uno de los gestos más importantes de la misa desde la Antigüedad tardía y hasta el final de la Edad Media: el beso de la paz. Durand recordaba sus fundamentos en los Evangelios y en las Epístolas

1 “Le baiser, dans l'Écriture sainte, signifie certainement l'union, la charité, la paix, le respect", Durand, G. 1854, Rational ou Manuel des Divins offices, t. II: 391 Paris: Louis Vivès. paulinas, así como en las costumbres de la "Iglesia primitiva", extendiéndose sobre todo en la enumeración de los motivos por los cuales el pueblo también participaba de ese gesto, incluyendo mandatos de los papas León II e Inocencio I. No dejaba de lado las advertencias necesarias para regularlo, como la separación de hombres y mujeres, para evitar "alguna indecencia", como "besos carnales" en un lugar donde todos los actos debían ser "castos y espirituales".2

Dejando de lado las consideraciones estrictamente litúrgicas, el beso de la paz podía significar mucho más desde una perspectiva social y cultural. De hecho, constituía uno

\footnotetext{
2 Ibídem: 387-392.
} 
de los momentos más importantes de la dimensión sacramental de la misa; es decir, de la representación simbólica de la unidad común entre Dios y los hombres, y sobre todo entre estos últimos, hecha posible gracias al sacrificio de Cristo en la Eucaristía que tenía lugar en el canon. Tal es la tesis que desarrolló de manera convincente John Bossy en dos artículos célebres publicados a principios de la década de 1980 en dos de las revistas de historia más prestigiosas de Francia e Inglaterra. ${ }^{3}$ Según su reconstrucción de los cambios de dicho ritual desde sus épocas más remotas, el beso se habría situado originalmente "como un saludo en el ofertorio, antes del sacrificio", ${ }^{4}$ pero ya desde el siglo V se desplazó hacia el momento de tomar la comunión, es decir, hacia el polo sacramental de la misa, que se fue construyendo progresivamente entre esa época y el siglo XIII. Es en ese lapso que se introducen en este punto del ritual tanto el Padre nuestro, como el himno del Agnus Dei, que justo terminará por entonarse al momento del intercambio del beso. ${ }^{5}$

Bossy insistía sobre todo en que, contrario a lo que los críticos de tiempos de la Reforma protestante apuntaban $-y$ también algunos historiadores- la misa era con claridad el gran ritual que unía a la sociedad medieval. ${ }^{6} \mathrm{Y}$ esto, a pesar de que nunca dejó de representar las divisiones entre los vivos y los difuntos, y sobre todo, entre amigos y enemigos, que llegaron incluso a traducirse en oraciones colectas específicas. ${ }^{7}$ Asimismo, a través de una amplia serie de debates y cuestionamientos, Bossy muestra que su parte más central, el sacrificio eucarístico, podía también devenir una representación de las divisiones más sensibles de la época, empezando por la superioridad del clero, único capaz de acceder de manera directa a las especies eucarísticas y muchas veces su único consumidor. El autor se detiene de manera particular en el tema de la fracción tripartita de la hostia consagrada, que lejos de ser una distribución armoniosa del pan en la comunidad, termina representando un acto de violencia y de división en su seno. ${ }^{8}$ Empero, la misa, lo reconocían tanto las autoridades como los fieles, estaba dotada de un poder sobrenatural difícil de imaginar hoy en día, ${ }^{9}$ y además justo gracias a los elementos que, como el beso de la paz, se habían introducido en su momento sacramental, era también un gran evento social para los fieles, marcado por el fin de la violencia. Lo reconocían también las autoridades religiosas, los comentaristas litúrgicos -ya lo hemos visto con el obispo Durand-decían con claridad que el beso era parte del camino constantemente renovado hacia el perdón, la paz temporal y, por fin, "la paz eterna del paraíso". ${ }^{10}$

A pesar de la trascendencia del beso tan argumentada por Bossy, las Reformas, tanto la protestante como la

3 Bossy, J. 1981. "Essai de sociographie de la messe, 1200-1700". Annales. Économies, Sociétés, Civilisations 36-1: 44-70 y Bossy, J. 1983. "The mass as a social institution, 1200-1700". Past and present 100: 29-61.

4 Bossy, J. 1983: 52.

5 Bossy, J. 1981: 60-61 y Bossy, J. 1983: 54-55.

6 Bossy parte de la recuperación de la visión de Weber sobre la importancia del culto medieval en el proceso de construcción de una moral universal.

7 Bossy, J. 1981: 49-54 y Bossy, J. 1983: 36-44 respectivamente.

8 Bossy, J. 1981: 54-58 y Bossy, J. 1983: 47-50 respectivamente.

9 Bossy, J. 1981: 46-47 y Bossy, J. 1983: 33-35 respectivamente.

10 Bossy, J. 1981: 60-61 y Bossy, J. 1983: 54. católica, lo suprimieron sin demasiadas dificultades. Ya el clero de finales del medievo lo veía con desconfianza, de forma que hubo intentos de moderarlo: pasó de la boca a la mejilla, y como ya mencionaba el obispo Durand, se impuso la separación de sexos para evitar toda confusión profana. Más todavía, desde el siglo xIII comenzaron a introducirse objetos intermediarios para la distribución de la paz: el osculatorium que el sacerdote besaba tras besar el altar para que acto seguido lo besaran también los fieles. En el mundo protestante, la eliminación de la misa y la concentración del ritual en el comentario de las Escrituras consagrarían el final del rito de la paz ${ }^{11}$, mientras que en el mundo católico se impuso un ritual que resaltaba la organización jerárquica de la Iglesia.

En efecto, lo podemos ver en las obras de liturgistas como Michael Bauldry y Bartolomé Gavanto. En ellas, si bien se hace alguna alusión a los argumentos que había expuesto Durand, ${ }^{12}$ lo importante es dejar clara la forma en que la paz había de distribuirse entre los clérigos, y sólo excepcionalmente a los laicos. Entre los primeros la paz seguía siendo un beso, al menos simulado, transmitido por el preste al diácono y por éste al conjunto de los sacerdotes presentes tanto en el altar como en el coro. La preocupación estaba en que la paz se distribuyera respetando estrictamente las jerarquías clericales. La paz se podía dar a los laicos, pero sólo per instrumentum (que en ningún caso podía ser la patena, aclaraban ambos autores citando decisiones de la Sagrada Congregación de Ritos), y no por el diácono sino por un acólito. ${ }^{13}$ Entonces, lo señalaba bien Bossy, "la Pax se convirtió en símbolo de discordia y no de amistad". ${ }^{14}$

En el mundo hispánico de los siglos XVI al XIX, la paz fue tanto más motivo de querella cuanto que el ceremonial religioso constituía uno de los recursos fundamentales para el ejercicio del poder. Una historiografía ya amplia lo ha demostrado: en la Monarquía Católica las autoridades tanto eclesiásticas como civiles no sólo se legitimaban a través del ritual sino que éste era uno de los terrenos fundamentales en que se construía su poder. ${ }^{15}$ Aún más, los reyes de

11 Véase Koslofsky, C. 2005 "The kiss of peace in the German Reformation", en Karen Harvey (ed.), The Kiss in History: 19-35. Manchester: Manchester University Press.

12 Sobre todo en Gavanto, B. 1763 Thesaurus Sacrorum Rituum, t. I: 262 Augusburgo: Matthei Rieger.

13 Ibídem: 278 y sobre todo Bauldry, M. 1703 Manuale Sacrarum Caeremoniarum, juxta ritum S. Romanae Ecclesiae: 178-179 Venecia: Paulum Balleonium.

14 Bossy, J. 1981: 62 y Bossy, J. 1983: 56.

15 Véase especialmente Cañeque, A. 2004 “De sillas y almohadones o de la naturaleza ritual del poder en la Nueva España de los siglos XVI y XVII". Revista de Indias 232: 609-634. La historiografía sobre el tema de las ceremonias de la monarquía en Nueva España es ya importante, aunque cabe decir que poco se ha interesado por los detalles de las ceremonias de la misa. Existen sobre todo trabajos a propósito de las representaciones del poder en el arte efímero de la fiesta barroca, por ejemplo: Mínguez, V. 1995 Los reyes distantes. Imágenes del poder en el México virreinal. Castelló de la Plana: Universitat Jaume I; Bravo Arriaga, M. D. 1998 "El otro rostro de Jano: Rituales y celebraciones en honor del 'Más claro Sol de las Españas', Felipe IV, 1666" en H. Pérez Martínez (ed.), México en fiesta: 329-337. Zamora: El Colegio de Michoacán. Para los otros reinos americanos se destaca en particular el trabajo de Jaime Valenzuela, hecho desde la perspectiva de legitimación del poder, quien aborda al menos el tema de la presentación del portapaz en el siglo XVII. Valenzuela, J. 2001 Las liturgias del poder: celebraciones públicas y estrategias persuasivas en Chile colonial (1609-1709): 249-250. Santiago de Chile: Centro de Investigaciones Diego Barrios Arana/ Ediciones Lom. 
Castilla y León, conviene tenerlo presente desde ahora, eran los Patronos de las Iglesias de sus dominios, en particular en los reinos de Indias, y en el siglo XVIII estimaban entre sus principales regalías la protección de la Iglesia. ${ }^{16}$

Aunque los liturgistas como Bauldry o Gavanto no nos lo dicen explícitamente, se sabe bien que las preocupaciones fundamentales de la Reforma católica por las ceremonias de la misa eran establecer la uniformidad del culto y reforzar su carácter sagrado, a través de la separación entre lo propio del clero y los laicos. ${ }^{17}$ La fuerte jerarquización que se advierte en el rito de la paz puede considerarse parte de esa lógica, mas de manera paradójica lo convertía también en un excelente terreno de disputas entre las autoridades de la monarquía. La liturgia de la Capilla Real es testimonio de su importancia: el padre Frutos Bartolomé de Olalla señalaba en su Ceremonial-separándose en ello de Bauldry y de Gavanto, sus principales fuentes- que al rey incluso "a diferencia de los demás seglares" se le podía dar la paz por el diácono y no por un acólito. ${ }^{18}$ Lo veremos enseguida, en el mundo hispánico el portapaz no sólo era regido por los libros litúrgicos y decisiones de las congregaciones romanas, sino también por la legislación civil.

Así pues, en este artículo nos interesan las querellas de la paz, es decir, las disputas políticas sobre la concesión del portapaz en el siglo XVIII novohispano, aunque sin perder de vista su importancia en tanto elemento de unas ceremonias que el clero estimaba también como fundamentalmente religiosas. Esas disputas datan, además, sobre todo de la época de las Reformas Borbónicas. Esto es, los reinados de Fernando VI, Carlos III y Carlos IV, en que según una historiografía ya amplia, se emprendió un proceso de modernización de la monarquía que se habría caracterizado, cierto que por una primera secularización de sus objetivos fundamentales, ${ }^{19}$ pero acaso también por un elevado

16 En general, el patronato de una iglesia consistía en el derecho que adquirían quienes fundaban, construían o dotaban iglesias o beneficios eclesiásticos para presentar a los clérigos titulares. En el caso del Patronato de las Iglesias de las Indias, se trataba a la vez de una regalía y privilegio pontificio, implicaba que era el rey quien podía erigir nuevas iglesias y presentar los titulares de beneficios eclesiásticos mayores y menores para su consagración y colación. Murillo Velarde decía que era "el derecho o facultad de presentar a un clérigo para establecerlo en una iglesia o beneficio", el mismo autor abordaba también el tema de los honores del patrono, incluida la paz. Murillo Velarde, P. 2005 Curso de derecho canónico hispano e indiano: v. 3, 288-291 en particular. Zamora, El Colegio de Michoacán/UNAM-Facultad de Derecho. Una explicación detallada sobre el Patronato de los reinos de Indias y su evolución en De la Hera, A. 1992 Iglesia y Corona en la América española. Madrid Mapfre. "La grande regalía de protección " sobre la Iglesia aparecía mencionada por ejemplo en el tratado de Covarrubias, J. 1783 Máximas sobre recursos de fuerza y protección con el método de introducirlos en los tribunales: 170. Madrid: imprenta de la viuda de Ibarra. Desde luego el rey católico no era el único que se estimaba con responsabilidades protectoras sobre lo sagrado, como muestra Cabantous, A. 2004. Entre fêtes et clochers. Profane et sacré dans l'Europe moderne, $\mathrm{XVII}{ }^{e}-\mathrm{XVIII} I^{e}$ siècle: 82-85. Paris: Fayard.

17 Martin, P. 2010 Le théâtre divin. Une histoire de la messe, $X V l^{e}-x X^{e}$ siècle: 10-18. París: CNRS Editions. Destaquemos que esta síntesis, hasta donde sabemos la más amplia de la historia del misa en el período que abordamos, omite el ritual de la paz en su descripción de las ceremonias.

18 De Olalla y Aragón, F. B. 1696 Ceremonial de las misas solemnes cantadas con diáconos o sin ellos, según las Rúbricas del Misal Romano, últimamente recognito por Su Santidad Urbano VIII: 170 Madrid: Juan García Infanzón impresor.

19 Lempérière, A. 2004 Entre Dieu et le roi: La république. Mexico, $X V I^{e}-X I X^{e}$ siècles: 150-156. París: Les Belles Lettres. autoritarismo y centralización del poder en los representantes regios, en particular los militares y oficiales fiscales. ${ }^{20} \mathrm{El}$ análisis de las querellas sobre el tema de la paz nos permitirá valorar esas transformaciones en el campo mismo en que se habían desarrollado tradicionalmente las disputas de poder del mundo hispánico.

Para comprender pues, estos "reinos de la confusión" -por retomar la expresión de Alain Cabantous-, ${ }^{21}$ en una primera parte nos adentraremos en el punto que ya hemos adelantado, el de la legislación, tomando en cuenta la otra gran fuente de derecho del mundo hispánico: la costumbre local. En segundo lugar entraremos ya en la materia, examinando los reclamos por el portapaz procedentes de los vicepatronos y otros magistrados regios. En fin, en una tercera parte, veremos a las otras autoridades que tomaron esa iniciativa, los representantes del público, en el sentido tradicional de las comunidades organizadas y gobernadas que integraban el cuerpo de la monarquía, ${ }^{22}$ y que cabe decir desde ahora, tuvieron muchas veces éxitos más importantes en este ámbito que las autoridades regias.

\section{LEYES, COSTUMBRES Y TENSIONES DEL PORTAPAZ}

Las querellas de la paz que nos interesan aquí no eran una novedad en el mundo hispánico en general, ni menos aún en los reinos americanos en particular. Para el siglo XVIII, por tanto, existía ya una amplia legislación sobre esta materia, construida a lo largo de los siglos XVI y XVII, normalmente a partir de querellas resueltas por los monarcas en su Consejo de Indias. Vamos a tratar de seguir aquí los puntos principales de su desarrollo.

Podemos ver algunas de las disposiciones más antiguas en la materia en el Gobierno eclesiástico pacífico de Hipólito de Villarroel. Quien había sido obispo de Santiago de Chile en el siglo XVII, citaba dos cédulas reales que databan ya de la década de 1570, una confirmando un auto del obispo de Quito disponiendo que se diera la paz al presidente y oidores de la Real Audiencia por un sacristán "u otra persona para ello diputada" (1573), y la otra resolviendo que al oidor más antiguo de la Real Audiencia de Guadalajara no debía dársele la paz por el diácono, como ocurría con el virrey de México (1578). ${ }^{23}$ La que parece haber sido la más general de las medidas de la monarquía en la materia que nos ocupa data de una década después, la real cédula dada el 29 de junio de 1588 mandando que las ceremonias de

20 Véase especialmente la obra ya clásica de Brading, D. 1975 Mineros y comerciantes en el México borbónico (1763-1810): 57-132. México: Fondo de Cultura Económica. Una síntesis para el conjunto de los reinos americanos: Brading, D. 1991 "La España de los Borbones y su Imperio Americano", en L. Bethell (ed.), Historia de América Latina, vol. 2: América Latina Colonial: Europa y América en los siglos XVI, XVII, XVIII: 85-126. Barcelona: Crítica / Cambridge University Press.

21 Cabantous, A. 2004:27.

22 Lempérière, A. 1998. "República y publicidad a finales del Antiguo Régimen (Nueva España)" en F.-X. Guerra y A. Lempérière (coords.), Los espacios públicos en Iberoamérica. Ambigüedades y problemas. Siglos XVIII-XIX: 54-79. México: Fondo de Cultura Económica/ Centro Francés de Estudios Mexicanos y Centroamericanos.

${ }_{23}$ Villarroel, G. 1703 Gobierno eclesiástico-pacífico y unión de los dos cuchillos pontificio y regio, t. II: 39-40. Madrid, Antonio Marín. 
la Capilla Real se guardaran con los virreyes. ${ }^{24}$ Si bien quedaba así claramente establecido que la paz debía darse a estos representantes del monarca y la manera de hacerlo, no aclaraba cuál era el ministro que debía llevarla, que según parece había sido el primer problema suscitado en los reinos americanos. La tercera y "más moderna" cédula citada por el obispo Villarroel, dada el 20 de marzo de 1602, definía un punto fundamental, la concurrencia entre obispos y presidentes de Audiencia para el caso de La Plata:25 había de darse la paz primero al prelado si estaba oficiando en la capilla mayor, y debía darse simultáneamente a él y al magistrado real si estaba en el coro. Empero, la real cédula dejaba el punto del ministro portapaz a los libros litúrgicos, mandando que "en cuanto a las personas que la han de llevar, se guarde lo dispuesto por el Ceremonial". ${ }^{26}$

La legislación real se iba construyendo en la resolución de los problemas que se iban presentando localmente, pero no dejaba de considerar los libros litúrgicos de la Reforma católica, que asimismo se iban publicando en la segunda mitad del siglo xvı. Más que el Misal Romano y sus rúbricas, en el caso de la paz como en el de otras cortesías, la legislación remitía al Ceremonial de los Obispos, publicado en 1600. Esto sin duda porque los conflictos se planteaban entre magistrados reales y obispos, o bien se esperaba que el oficiante de las ceremonias ante un magistrado real fuera al menos un clérigo de alta jerarquía.

Empero, el Ceremonial no siempre era útil. Ya el obispo Villarroel lo había advertido, aunque sin apuntar el problema principal: los libros litúrgicos no tenían las mismas preocupaciones de los magistrados reales. Es cierto, el Ceremonial de los Obispos, trataba el tema de la paz en al menos dos ocasiones. Primero en doce puntos del capítulo xxIV del libro I. Claramente el problema ahí era el respeto de la jerarquía del clero y en particular de los obispos, como cabía esperar. Se mencionaba a los seglares en dos puntos únicamente: en el 5, sobre las reverencias que debían hacerse a los "príncipes supremos" a quienes se daba la paz, y en el siguiente, especificando que debía darse la paz a los laicos "con instrumento" y por el presbítero asistente de la celebración. Mas no se detallaba ni siquiera cuál debía ser el instrumento para dar la paz, ni tampoco se abundaba en las características del ministro asistente. ${ }^{27}$ El tema aparecía de nuevo en el libro III, dedicado a las ceremonias para presidentes, gobernadores, prelados y vicelegados. Todo ello estaba sin duda en el marco del Estado Pontificio, donde, según ha mostrado la historiografía reciente, los representantes del Papa en tanto monarca solían tener enfrentamientos con los obispos no menos complicados que en las otras monarquías del mundo católico. ${ }^{28}$ Empero, en este

24 Recopilación de Leyes de Indias, libro III, título 15 “De las precedencias, ceremonias y cortesías", ley X, versión digital, http://www.congreso.gob.pe/ntley/LeylndiaP.htm, consultado el 8 de enero de 2013.

25 Villarroel, G. 1703, t. II: 41.

26 Ídem.

27 Hemos utilizado la versión corregida bajo el pontificado de Benedicto XIV. 1827 Caeremoniale episcoporum: 77. Nápoles: Typographia Simoniana.

28 Prodi, P. 2010. El soberano pontífice. Un cuerpo y dos almas: La monarquía papal en la primera Edad Moderna: 225-268 Madrid: Akal, en particular p. 245, con el ejemplo de Bolonia: entre los problemas suscitados entre el obispo y el gobernador civil enviado por el Papa había caso se limitaba a mandar que se incensara a las autoridades al mismo tiempo que los canónigos en el coro. ${ }^{29}$

La ley, pues, remitía al Ceremonial y éste no daba respuestas ciertas, entonces ¿qué alternativa quedaba en este caso? No es de extrañar que el propio diocesano de Santiago de Chile sentenciara cuál era el recurso a utilizar: "Este caso debe reducirse a la costumbre". ${ }^{30}$ Esto es, ya desde el siglo XVII, en materia del portapaz existían tres fuentes de derecho fundamentales: no sólo las leyes reales, que se iban acumulando progresivamente; no sólo los libros litúrgicos, que se iban expandiendo por todo el mundo católico; sino también la costumbre local. ${ }^{31}$

¿De qué forma podía intervenir la costumbre? Podía ser una forma de prevenir conflictos, situando a un mismo nivel a las autoridades civiles y eclesiásticas, como advertía ya el mismo obispo Villarroel, en cuya Catedral se había hecho costumbre que se diera la paz al mismo tiempo a él y a la Audiencia, no importando si el prelado estaba en la capilla mayor o en el coro. "Nunca se sobra en las cortesías con semejantes personas", afirmaba el prelado. ${ }^{32}$ Mas una misma solución consuetudinaria podía tener consecuencias distintas, como se ve a detalle en la querella que originó la reforma en materia del portapaz introducida por el deán de la Catedral de Durango, Dr. Francisco Gabriel Olivares y Benito, en 1766. Lo explicaba el gobernador de Nueva Vizcaya, Joseph Carlos de Agüera, la costumbre ahí, como en Santiago de Chile, era que "se dé la paz a un mismo tiempo a gobernador del reino y canónigos", con dos "ministros portapaces" que bajaban al mismo tiempo del altar mayor, uno hacia el coro y el otro hacia el asiento del magistrado. Sin embargo, por la proximidad del asiento de este último, esta solución beneficiaba a su autoridad, pues terminaba recibiendo la paz antes que los canónigos por una "necesaria preferencia" según su propio decir. ${ }^{33}$ Tendría que llegar a la catedral duranguense un deán celoso de la jerarquía clerical como fue el doctor Olivares y Benito para que esta costumbre fuera cuestionada. ${ }^{34}$

Mas volvamos todavía sobre el desarrollo de la legislación: cabe destacar que fue a finales del siglo que llegó a adquirir formas definitivas con la publicación, en 1680, de la Recopilación de Leyes de Indias. La materia que nos ocupa

temas de ceremonias, en particular la bendición del incienso en la misa y la organización de procesiones.

29 Caeremoniale. 1827: 244.

30 Villarroel, G. 1703: 41. Bien afirmaba el profesor Thomas Duve para otro tipo de problemática, "todo el derecho de la época [el Antiguo Régimen en este caso] tiene que ser leído frente a un 'trasfondo consuetudinario' que lograba integrar la diversidad de fuentes, su disparidad, admitiendo adaptaciones y actualizaciones de la normativa y eligiendo lo apto para el caso concreto..." Duve, T. 2010. "Catequesis y derecho canónico entre el Viejo y el Nuevo Mundo", en R. Schmidt-Riese (ed.), Catequesis y derecho en la América colonial. Fronteras borrosas: 132133. Madrid: Iberoamericana-Vervuert.

31 "Las costumbres constantes, aprobadas por el consentimiento de los que las usan, se asemejan a la ley", decía citando a Justiniano el padre Murillo Velarde al abordar la costumbre como fuente de derecho: Murillo Velarde, P. 2005: v. 1, 282-287.

32 Ídem.

33 AGI, Guadalajara, leg. 334, exp. 6, fs. 843-846v, representación del gobernador de Durango, 17 de febrero de 1766.

34 El doctor Olivares y Benito parece haber estado preocupado de manera particular por moderar la participación de las autoridades civiles en las ceremonias sagradas. Sus principales querellas con los gobernadores y munícipes de Durango fueron a propósito de la llave del depósito del Santísimo Sacramento el Jueves Santo. AGI, Guadalajara, leg. 584. 
se integró en el título 15 del libro III, dedicado a las "precedencias, ceremonias y cortesías". En él aparecen las reales cédulas de 1588 y 1602 que ya hemos mencionado, para un total de siete disposiciones, dictadas mayormente en el propio siglo XVII. ${ }^{35}$ Los puntos que aclaraban son por sí mismos interesantes: la legislación tendía a hacer del portapaz un objeto exclusivo del monarca y sus representantes actuando en tanto tales. Lo vemos por ejemplo en las repetidas cédulas de Felipe II y Felipe III que entraron a la Recopilación mandando que no se diera la paz sino a las Reales Audiencias en cuerpo y no a sus integrantes en particular: no era pues un honor de los oidores solos, sino del tribunal regio en su conjunto. ${ }^{36}$ Otro tanto se aprecia en la disposición de Felipe IV de incluir también a los gobernadores y capitanes generales en el uso del portapaz, en tanto que en muchas regiones de los reinos americanos estos magistrados, aparentemente menores, eran a veces los únicos representantes de la presencia del monarca. ${ }^{37}$ Cabe advertirlo, la legislación pareciera haber tratado de crear una jerarquía más o menos clara de la recepción de la paz: los virreyes de mano de un diácono, al igual que el rey, privilegio que lo situaba por encima de lo dispuesto en la liturgia; los demás magistrados citados en las Leyes de Indias se entiende que tendrían que haberse conformado con recibirla de manos de acólitos, sacristanes o como se decía en el caso de gobernadores y capitanes generales, "un clérigo con sobrepelliz y estola". ${ }^{38}$ Un nivel más abajo estaban los oficiales de la Real Hacienda, los Contadores de Cuentas, a los que la propia ley dejaba a la costumbre darles o no la paz. ${ }^{39}$

Dos disposiciones del reinado de Felipe IV dadas en 1630 y 1642 y que llegaron también a las Leyes de Indias, ${ }^{40}$ señalaban, sin embargo, una excepción importante: dos ayuntamientos, los de las Cortes de México y de Lima, recibieron el privilegio de la paz, pero acotado de manera muy particular: "no concurriendo los virreyes o Audiencias". Debemos subrayarlo porque será un punto que reaparecerá en las querellas que veremos más adelante. En ausencia de los representantes de la Majestad y su justicia, incluso unos representantes del público, cierto que de ciudades particularmente privilegiadas, podían aspirar a la presentación del portapaz ${ }^{41}$.

Ahora bien, ninguna de las disposiciones recogidas en la Recopilación hizo alusión alguna al tema del Patronato, pues como hemos dicho están en el libro III, título 15 y no en el libro I, título 6 que es el que corresponde a este último tema. Los libros litúrgicos y las obras de los liturgistas no hacen alusión sino a los seglares y en todo caso a los "príncipes supremos", pero no a los patronos cuando se trataba de la paz. Empero, entre los tratadistas ya del siglo XVIII era

${ }^{35}$ Recopilación de Leyes de Indias, libro III, título 15, leyes XVII-XXIII.

36 Ibídem, ley XVIII.

37 Ibídem, ley XX.

38 Ibídem, leyes X, XVIII y XX.

39 Ibídem, ley XXII.

40 Ibídem, ley XXI.

41 Adelantemos desde ahora que, como observa Valenzuela, con esta ley "se otorgaba un subterfugio para que el resto de los cabildos americanos asumieran este rito en forma de costumbre y como una prerrogativa local". El mismo autor da cuenta del reclamo del cabildo de Santiago de Chile para obtener la presentación del portapaz en 1681, citando el ejemplo de los ayuntamientos de Charcas, Cuzco, Guamanga, Tucumán y Buenos Aires. Valenzuela, J. 2001: 250. bien posible asociar la paz al Patronato. Lo hizo explícitamente don Antonio Joaquín de Rivadeneyra en su Manual Compendio del Regio Patronato, quien citaba entre los privilegios del Patronato canónico, no sólo la presentación de los titulares de los beneficios patrocinados, sino también "ocupar el primer asiento en la Iglesia" y lo que importa para nuestros fines, "recibir la paz en el lugar primero". ${ }^{42}$ La observación del jurista es tanto más significativa cuanto que el patronato del rey sobre las Iglesias de los reinos de Indias sería asimismo citado en varias ocasiones en las querellas sobre el tema. Así fue en el caso de Durango: el gobernador Agüera firmó un decreto dando cuenta de todas sus quejas contra el deán Olivares y Benito en 10 de noviembre de 1766, insistiendo en su calidad de vicepatrono de la Iglesia de Durango, es decir, el clérigo cometía un atentado no sólo contra él, sino contra una de las más importantes regalías de la Corona. ${ }^{43}$

A lo largo de los siglos XVI y XVII pues, se fueron construyendo las normas que regían el uso del portapaz en Nueva España: los libros litúrgicos que aplicaban para el mundo católico en su conjunto, las leyes imperiales producto de las primeras querellas y las costumbres locales que sancionaban los equilibrios en los espacios dejados por las dos anteriores. Sin duda, no faltaban las tensiones, como nos lo ha mostrado la querella de Durango en 1766, que es prueba de que había entonces, en la segunda mitad del siglo XVIII, clérigos con voluntad de aplicar de manera estricta las jerarquías consagradas por los libros litúrgicos más allá de las costumbres recibidas, y también magistrados reales y autoridades eclesiásticas que, como algunos autores regalistas, asociaban el portapaz al Real Patronato. Es en este contexto que las reformas borbónicas comienzan a crear nuevas magistraturas o a reforzar otras, generando nuevas querellas por el portapaz que tuvieron por escenario las catedrales de Puebla de los Ángeles y Guadalajara de Indias.

\section{PORTAPAZ, VICEPATRONATO Y SACRALIDAD}

La asociación del portapaz y el vicepatronato no era una novedad de la época de las Reformas Borbónicas. Ya en 1757 Martín de Reynoso Mendoza, alcalde mayor de Valladolid de Michoacán había alegado que era "juez subdelegado del Real Patronato de Su Majestad" como un motivo para exigir que se le diera la paz en la Catedral y demás iglesias de esa ciudad. Aunque consiguió que se le diera efectivamente en los conventos agustino y franciscano, fracasó ante los canónigos y ante los carmelitas, cuyo prior, fray Lázaro de San José, aceptó que se le recibiera en la iglesia con toda formalidad, se le pusiera banca forrada y se le diera agua bendita, pero se negó a concederle el portapaz. ${ }^{44}$ El caso llegó

42 Rivadeneyra, A.J. 1755 Manual compendio del Regio Patronato Indiano: 35. Madrid: Antonio Marín.

43 AGI, Guadalajara, leg. 334, exp. 13, fs. 910-913.

44 AGI, México, leg. 2662, "Testimonio de los autos de fuerza seguidos por D. Martín de Reynoso Mendoza y Luyando [...] sobre lo acaecido el día 15 de octubre del año de 1757 en el convento de religiosos carmelitas descalzos de esta ciudad y de la real provisión expedida en el asunto y auto acordado sobre el punto de ceremonias con el M. I. Ayuntamiento, justicia y regimiento de esta dicha ciudad", especialmente fs. 17-21v. 
hasta la Real Audiencia de México, cuyo fiscal, el Marqués de Aranda, dictaminó en noviembre de ese mismo año que, conforme a las Leyes de Indias, el portapaz era un privilegio exclusivo de los virreyes, presidentes y ministros de las Reales Audiencias en cuerpo, gobernadores de las provincias y ayuntamientos de México y Lima. ${ }^{45}$

El fiscal evadió el punto del vicepatronato, pero la Audiencia se conformó con la idea de que no cualquier alcalde mayor podía aspirar a la recepción de la paz. Pero ¿qué sucedía en el caso de otros magistrados locales? Justo en esa década de 1750 un cambio en la organización del gobierno local novohispano dio la oportunidad de plantear el problema. Se sabe bien en la historiografía, el siglo XVIII fue una época de reorganización del gobierno provincial de Nueva España. El cambio más conocido, y sin duda el más importante, fue el establecimiento del régimen de provincias-intendencias a finales de la década de $1780 .{ }^{46} \mathrm{Sin}$ embargo, ya antes hubo modificaciones en la jerarquía de los magistrados que gobernaban algunas de las ciudades novohispanas. Hasta 1754, la segunda ciudad más importante del reino, Puebla de los Ángeles, había sido gobernada por un magistrado con título de alcalde mayor, que entonces fue elevado a gobernador político y militar. ${ }^{47}$ Para significar dicho cambio, en la década siguiente uno de los titulares de la nueva gubernatura, el coronel Esteban Bravo de Rivero, emprendió varios procedimientos para que se le otorgaran diversos honores en sus asistencias a la Catedral, comenzando por el asiento en silla con tapete y almohada, que obtuvo en real cédula de 21 de octubre de 1764, siguiendo luego con la aspersión de agua bendita y la presentación del portapaz, que reclamó ya en 1766 al obispo Francisco Fabián y Fuero y su Cabildo Catedral. ${ }^{48}$

Este caso lo hemos examinado ya en otros momentos a propósito de otros honores, y ha sido ya estudiado por otros autores. ${ }^{49}$ Nos limitaremos por tanto a señalar, sobre el portapaz en concreto, que fue el más importante tema de la querella, en primer lugar, que fue el clero quien trató

\footnotetext{
45 Ibídem, fs. 111-118v.

46 El estudio clásico sobre este tema es: Pietschmann, H. 1996 Las reformas borbónicas y el sistema de intendencias en Nueva España. Un estudio político administrativo. México: Fondo de Cultura Económica. Una revisión particularmente interesante de la historia administrativa de las reformas en Sánchez de Tagle, E. 2010. "Las reformas del siglo XVIII al gobierno; la ciudad, su hacienda, su policía, su ejército", en C. García Ayluardo (coord.), Las reformas borbónicas, 1750-1808: 164224. México: CIDE/ Fondo de Cultura Económica/ Conaculta / INEHRM/ Fundación Cultural de la Ciudad de México.

47 Liehr, R. 1976 Ayuntamiento y oligarquía en Puebla, 1787-1810: 123. México: Secretaría de Educación Pública. Este nuevo magistrado tuvo un papel importante en la reorganización militar del reino a nivel local, según destaca ya Ramos, F. L. 2010 “Creando sujetos reales a través de las Reformas Borbónicas: La corona, el cabildo y la manipulación de la ceremonia de la 'segunda ciudad' del reino", en XIII Reunión de historiadores de México, Estados Unidos y Canadá: 3. Querétaro, versión digital http://13mexeuacan.colmex.mx/Ponencias\%20PDF/Frances\%20 Lourdes\%20Ramos.pdf.

48 AGI, México, leg. 1269, representación del coronel D. Estaban Bravo de Rivero, 21 de enero de 1768 y carta del gobernador al obispo de Puebla, Puebla, 22 de agosto de 1766.

49 Especialmente por: Ramos, F. L. 2010: 12. Ramos, F. L. 2010 "Negociar el poder y reafirmar la fe en la Puebla del siglo XVIII. Los cabildos y la solución de los conflictos en el ámbito ceremonial", en F. J. Cervantes Bello (coord.), La Iglesia en la Nueva España: relaciones económicas e interacciones políticas: 257-289, en particular 274-275 Puebla: Benemérita Universidad Autónoma de Puebla.
}

de evitar se concediera este honor al gobernador, asociándolo al vicepatronato. En efecto, al primer intento de Bravo de Rivero en agosto de 1766, respondió el obispo poco más de un mes después, que "no parece correspondiente al empleo de gobernador que no ejerce el Real Patronato, una ceremonia debida a los señores virreyes y presidentes, en quienes reside". ${ }^{50}$ En cambio, el gobernador logró obtener el acceso al portapaz gracias al dictamen del fiscal del Consejo de Indias de 26 de febrero de 1768, quien justo negó su asociación con el vicepatronato citando para ello como autoridad el Ceremonial de los Obispos: la paz, afirmaba, "no se da a los gobernadores como vicepatronos y capitanes generales, sino como cabeza del estado secular, y para denotar la unión que debe haber entre él y el eclesiástico". ${ }^{51}$

Empero, los miembros del Consejo fueron sensibles a uno de los argumentos del clero poblano, el de guardar la jerarquía entre el virrey y el gobernador. La real cédula de 29 de marzo de 1768 justo apuntó, en ese sentido, que Bravo de Rivero debía recibir la paz de un clérigo de sobrepelliz y no del diácono, como ocurría con el virrey, según hemos visto antes. ${ }^{52} \mathrm{Al}$ darle cumplimiento a dicho rescripto, los canónigos de Puebla fueron un poco más allá. El doctoral Manuel Ignacio de Gorozpe dictaminó, fundado según su propio decir, en el "espíritu" de las leyes de Indias en la materia, que la paz se daría al gobernador por "el eclesiástico que con sobrepelliz diere la paz en el coro, acabada allí asimismo esta ceremonia". ${ }^{53}$ Esto es, se le daría al gobernador la paz, pero sólo después de toda la jerarquía del clero, músicos incluidos como advirtió de inmediato Bravo de Rivero.

En efecto, el gobernador alegó a su favor la ley XXIII, título 15, libro III de la Recopilación, que mandaba que en concurrencia de obispo y gobernador se hiciera lo mismo que con virreyes y presidentes, dar la paz primero al obispo, si se encontraba en la capilla mayor, y simultáneamente a uno y otro si estaba en el coro. ${ }^{54}$ Bravo de Rivero pedía además que esto último se extendiera a la ausencia del obispo de su iglesia, es decir, cuando concurrieran únicamente los cabildos eclesiástico y secular, este último, claro está, presidido por él.

La protesta del magistrado dio oportunidad a que el canónigo doctoral se extendiese en su justificación de la postura del Cabildo Catedral. Su principal argumento no era otro en realidad que la "preferencia" en las ceremonias "a todo el estado eclesiástico, respecto a los seculares", esto es, la jerarquía del clero. El doctoral explicó con cierto detalle esta superioridad, debida al "ministerio que ejercita", y que comparaba incluso con la santidad de la Iglesia, vigente a pesar "los defectos de algunos de sus individuos". Para él, y lo repetirían en varios momentos los canónigos, sólo la

50 AGI, México, leg. 1269, el obispo de Puebla al gobernador Esteban Bravo de Rivero, Puebla, 28 de septiembre de 1766.

51 Ibídem, resolución del Consejo de Indias, 10 de marzo de 1768 y real cédula de 29 de marzo de 1768.

52 Ídem.

53 Ibídem, "Testimonio de las diligencias practicadas en orden al distintivo de la aspersión del agua bendita y de la paz que pretenden el señor gobernador de esta ciudad", f. 14, informe del canónigo doctoral, Puebla, 19 de octubre de 1768.

54 Ibídem, "Testimonio de las diligencias practicadas...", fs. 29v-35, el gobernador al deán y Cabildo Catedral de Puebla, 18 de mayo de 1769. 
"representación del príncipe" podía justificar una excepción, y claramente Bravo de Rivero no gozaba de ella de manera plena por ubicarse en la categoría de aquellos que "reconocen superioridad", en este caso, la del virrey ${ }^{55}$. En fin, el Cabildo Catedral en su conjunto respondió al gobernador agregando además el argumento de la sacralidad de las ceremonias; es decir, la materia de la disputa era "espiritual o conjunta a la misma espiritualidad del sacrificio de que dimana"; por supuesto, los canónigos se declaraban sin facultades para "alterar las ceremonias sagradas", y por tanto para conceder la petición del gobernador. ${ }^{56} \mathrm{El}$ obispo Fabián y Fuero respaldó a los canónigos ya a principios de 1770 citando incluso "decisiones de la Sagrada Congregación de Ritos", que no llegó a precisar. ${ }^{57}$

La defensa del Cabildo Catedral de Puebla es sin duda uno de los mejores ejemplos de que la participación del rito de la paz era una cuestión sagrada que ordenaba varias jerarquías: la del clero por encima de los seglares, la de la Santa Sede -definidora de los ritos sagrados- sobre el conjunto de la Iglesia católica, la del rey y sus representantes vicepatronos por encima de los demás magistrados, por supuesto, la del rey y sus magistrados sobre sus súbditos, para quienes la paz estaba directamente vedada, e incluso una jerarquía de género: aun si no venía directamente al caso, el doctoral Gorozpe no dejó de recordar que el portapaz estaba prohibido a cualquier mujer. ${ }^{58}$ En el fondo, el alto clero poblano no veía en el coronel Bravo de Rivero sino un magistrado incorporado en una corporación municipal, como lo dijo expresamente el obispo Fabián y Fuero al virrey en diciembre de 1769: al gobernador, sentenciaba, "no le corresponde otro honor que el debido al presidente del Ayuntamiento". 59

La argumentación del coronel Bravo de Rivero fue mucho más básica, pues se limitó a pedir una y otra vez el cumplimiento de la ley XXII, título 15, libro III de la Recopilación de Indias. Sin embargo, en una carta que dirigió al virrey en noviembre de 1769 , es posible ver que también el gobernador reconocía el rito de la paz como ceremonia sagrada, pero con matices que le permitían acceder a él de manera mucho más sencilla que en la estricta perspectiva del obispo y Cabildo Catedral poblanos. Lo esencial era la distinción que planteaba la ley entre el obispo en la capilla mayor o el coro, en el primer caso el prelado "interviene en el Sacrificio", de hecho presidiéndolo, por lo que debía dársele la paz ante todo; en cambio, estando en el coro, el obispo y el gobernador debían recibir la paz simultáneamente. La ley pues garantizaba ya la protección de la jerarquía superior de lo sagrado que tanto preocupaba a los clérigos, pero protegía también la potestad de los magistrados cuando los

\footnotetext{
55 Ibídem, "Testimonio de las diligencias practicadas...", fs. 37v-42, informe del canónigo doctoral, Puebla, 23 de mayo de 1769.

56 Ibídem, "Testimonio de las diligencias practicadas...", fs. 44-48, el Cabildo Catedral de Puebla al gobernador, 4 de julio de 1769.

57 Ibídem, representación del obispo de Puebla, Madrid, 16 de marzo de 1770.

58 Véase el informe citado en la nota 52.

59 Ibídem, testimonio anexo a la carta del virrey de Nueva España de 4 de enero de 1770, el obispo de Puebla al marqués de Croix, Puebla, 9 de diciembre de 1769 .
}

obispos no se hallaban en contacto directo con el sacrificio del altar. ${ }^{60}$

Al final, el 3 de julio de 1770, el Consejo de Indias mandó guardar y observar la ley de Indias, sin ser más explícito en cuál de los contendientes llevaba razón en sus argumentos, aunque bien podemos imaginar que la resolución podía leerse como un triunfo del gobernador Bravo de Rivero. ${ }^{61}$ De la conclusión de esta querella podría decirse que el portapaz había de regirse, ante todo por la ley de Indias y que no estaba necesariamente asociado al vicepatronato. Esto se confirma en la decisión del fiscal y miembros del Consejo unos años más tarde a propósito de la representación que les dirigió Eusebio Sánchez Pareja, regente de la Real Audiencia de Guadalajara. ${ }^{62}$

Conviene recordarlo, así como el coronel Bravo de Rivero, Sánchez Pareja estaba en un cargo de nueva creación en el tribunal tapatío y en general en los tribunales americanos, el de Guadalajara hasta entonces encabezado por un presidente y gobernador de la Nueva Galicia. Esta medida era parte de la reforma de los tribunales de tiempos de los Borbones. ${ }^{63}$ Esto es, así como en Puebla, nos encontramos con una magistratura producto de las reformas, que seguía estimando indispensable el acceso al portapaz como parte de su autoridad. Al asumir su encargo, el regente trató de identificar con claridad los honores que le correspondían en sus asistencias a la Catedral, encontrando varias contradicciones. A propósito de la presentación del portapaz, una real cédula de 1686 asentaba que estaba entonces en uso que al presidente de la Audiencia tapatía se le diera por el subdiácono y mandaba que le acompañara además el sacristán mayor u otro clérigo; esto lo contradecía otra real cédula de 1728, que mandaba explícitamente guardar la ley de Indias y el Ceremonial de los Obispos, prohibiendo que bajaran el diácono y el subdiácono, sino sólo el sacristán mayor. Además, los testigos que rindieron declaración por orden de la Audiencia afirmaron que estaba en uso que se le diera la paz al presidente "un capellán de coro con sobrepelliz, estola y almaizal". ${ }^{64}$ Estas variaciones nos confirman que el tema del portapaz había estado sometido a las variaciones de los equilibrios de poder entre las dos grandes corporaciones civil y eclesiástica de Guadalajara, hasta el punto que la costumbre en realidad no era necesariamente estable. EI nuevo regente trataba de recuperar terreno, volviendo a la real cédula de 1686, fundándose para ello en el Patronato. En efecto, cerraba su representación sentenciando que la

60 Ibídem, testimonio anexo a la carta del virrey de Nueva España de 4 de enero de 1770, el gobernador de Puebla al virrey, Puebla, 11 de noviembre de 1769.

61 Ibídem, resolución del Consejo de Indias, 3 de julio de 1770.

62 AGI, Guadalajara, leg. 343, resolución de la sala 1ạ del Consejo de Indias, 19 de febrero de 1779.

63 Vale la pena citar la obra clásica de Buckholder y Chandler: "La creación de este cargo fue uno de los diversos medios con que la Corona trató, a partir de 1750, de limitar la autoridad de los funcionarios ejecutivos de América". Buckholder, M. A. y D. S. Chadler 1984 De la impotencia a la autoridad. La Corona española y las Audiencias en América, 16871808: 140-146, la cita en 144. México: Fondo de Cultura Económica.

64 AGI, Guadalajara, leg. 343, "Testimonio del expediente formado sobre el ceremonial que se observa con el señor regente de esta Real Audiencia por el ilustrísimo señor obispo y venerable señor deán y Cabildo de esta Santa Iglesia Catedral", información de testigos de 11 de junio-3 de julio de 1777 y certificación de 23 de septiembre de 1777. 
falta del honor del portapaz, y otros más, no podían sino "calificarse por una corruptela en agravio del Vice Patronato Real, y del reconocimiento que debe prestarle la Iglesia Patronada". 65

El vicepatronato, que había servido al clero poblano para negarle la paz al gobernador de Puebla, servía ahora al regente tapatío para reclamarla con mayores honores. Sin embargo, el Consejo resolvió de manera más bien coherente con el caso que hemos visto antes. El fiscal dictaminó en 8 de febrero de 1779, que si bien había pruebas en efecto de que a algunos gobernadores les daba la paz el subdiácono, el uso que se había probado en Guadalajara no tenía nada de "irracional, dañoso y abusivo", sino antes bien era conforme con la legislación recopilada y a las cédulas de 1725 y 1728. La costumbre y la ley se conciliaban bien en este caso, por lo que nada había que agregar, el fiscal, que debía ser Antonio Porlier, no llegó siquiera a plantearse que conceder la paz en los términos pedidos por Sánchez Pareja hubiera sido una buena forma de reforzar la autoridad de una nueva magistratura. La sala primera del Consejo de Indias no hizo sino conformarse con su fiscal, el 19 de febrero siguiente. ${ }^{66}$

El Patronato, señalemos para finalizar, podía también ser un argumento eficaz en otro sentido. A finales de la década de 1760 , en la propia ciudad de Guadalajara, los oficiales de la Real Hacienda lograron obtener la presentación del portapaz, fundándose en las Leyes de Indias y varias reales cédulas. Las primeras les permitían alegar un derecho por presentarse en la iglesia haciendo cuerpo con la Real Audiencia, las segundas, se presentaban como decisiones explícitas del rey en el sentido de darles todos los honores que disfrutaban ya sus homólogos de la Ciudad de México, tanto más importantes cuanto que el rey era Patrono de la Iglesia y "como a quien por él toca conceder estas preeminencias". ${ }^{67}$

Los canónigos de Guadalajara se defendieron arguyendo la costumbre: "siempre se ha tenido por ilegítima cualquiera alteración que se hace contra la costumbre", asentó con firmeza el chantre Ibarreta al inicio de su dictamen de octubre de 1767. El Cabildo Catedral contó incluso un apoyo inesperado: la propia Audiencia de Guadalajara, que descartó la idea de hacer un solo cuerpo con los oficiales reales; a pesar de ello, los oidores y los canónigos no pudieron evitar que el Consejo resolviera a favor de la petición de los oficiales reales. ${ }^{68}$ Aunque los canónigos tapatíos y poblanos se mostraron reticentes, era cierto que el coronel Bravo de Rivero, el regente Sánchez Pareja y los oficiales de Real Hacienda eran magistrados del rey, quien en efecto era Patrono de la Iglesia, y que los propios clérigos reconocían constantemente tenía también potestad para intervenir en esas

65 Ibídem, representación del Regente de la Audiencia de Guadalajara, 16 de enero de 1778.

66 Ibídem, dictamen del fiscal del Consejo de 8 de febrero de 1779 y resolución de la sala $1^{\text {a }}$ del Consejo de Indias, 19 de febrero de 1779.

67 AGI, Guadalajara, leg. 335, n. 14, fs. 750-753, representación de los oficiales reales de Guadalajara, 14 de junio de 1768.

68 Ibídem, "Testimonio de los autos formados a pedimento de los señores oficiales reales de la Real Caja de esta Corte, sobre la prevención de que se les dé la paz en las funciones de tabla y el agua bendita en la mano", fs. 759v-762v, dictamen del chantre del Cabildo Catedral de Guadalajara, 3 de octubre de 1767 y fs. 768v-771, dictamen del fiscal de la Real Audiencia, 22 de enero de 1768. "ceremonias sagradas". La Corona, repetimos, no parece haber tenido una política clara en la materia, por lo que no es de extrañar que favoreciera incluso a otros actores que también trataban de acceder al portapaz en esta misma época.

\section{LA PAZ DEL PÚBLICO Y EL SIGNIFICADO DEL RITO}

En la segunda mitad del siglo XVIII, al menos tres grandes corporaciones municipales reclamaron al rey en el Consejo de Indias que se les permitiera acceder al portapaz: los ayuntamientos de Valladolid de Michoacán, Puebla de los Ángeles y Guadalajara. Debemos destacarlo, se trata de ciudades entre las más importantes del reino de Nueva España después de la capital de México, que como hemos visto tenía garantizado el portapaz gracias a las Leyes de Indias. Eran sedes diocesanas, serían pronto capitales de provincias-intendencias, y sus ayuntamientos podían contarse entre los más antiguos y renombrados del reino. Empero, ninguno de los tres obtuvo el honor de la paz.

Conviene apuntarlo, las querellas de los magistrados locales que hemos visto antes fueron uno de los motivos que llevó a estos cuerpos urbanos a presentar sus solicitudes. Es particularmente claro en el caso de Puebla, que envió una representación al Consejo en 1770, cuyo único argumento original era que, presentándose el ayuntamiento en la iglesia haciendo cuerpo con el gobernador, quien acababa de obtener la presentación del portapaz, según hemos visto, no podía sino extenderse también a ellos. ${ }^{69}$ El fiscal del Consejo dictaminó negativamente, fundado justo en una de las leyes que citaban los munícipes poblanos, la que concedía la paz al ayuntamiento de México. Si el fiscal Marqués de Aranda afirmaba en México en 1757 que no cualquier magistrado del rey podía acceder al portapaz, en Madrid, Lanz Casafonda estimó que no cualquier ayuntamiento podía equipararse a los de México y Lima. ${ }^{70}$ La desigualdad de los honores, propia de la desigualdad entre los hombres, sería uno de los puntos recurrentes de estas querellas para el caso de los ayuntamientos. Lo decía el fiscal del Consejo, de extenderse el portapaz a todos los cabildos americanos, "dejaría de ser privilegio el que se dispensa por la referida [ley] al de Lima y México". ${ }^{71}$

Tal vez quien más se extendió en ese punto fue el doctoral del Cabildo Catedral de Michoacán, Vicente Antonio de los Ríos, en el propio año de 1770, que fue también la fecha en que el ayuntamiento de Valladolid emprendió sus gestiones para obtener el portapaz ante la Real Audiencia de México. ${ }^{72}$ El canónigo redactó la explicación más extensa

69 AGI, México, leg. 2662, representación del Ayuntamiento de Puebla, Madrid, 29 de mayo de 1770.

70 Ibídem, dictamen del fiscal del Consejo de Indias, Madrid, 29 de junio de 1770.

71 El Ayuntamiento obtuvo al menos que se le concediera la paz en presencia de su gobernador, y en su ausencia, sólo a quien lo presidiera en su lugar. Ibídem, resolución del Consejo de Indias, Madrid, 3 de julio de 1770.

72 La Real Audiencia solicitó un informe al Cabildo Catedral, que respondió con varias certificaciones e información de testigos sobre la costumbre vigente, completado con el extenso informe del doctoral De los Ríos. AGI, México, leg. 2662, testimonio adjunto a la representación 
de que tenemos noticia hasta ahora sobre los motivos para negarle la paz al ayuntamiento, remontándose a los orígenes mismos del rito. Preparación para recibir la Eucaristía, el beso de la paz era "señal de unión y caridad cristiana", práctica de una época en que "florecía más entonces la virtud"; lo veían ya los actores de la época, el rito había tenido una transformación radical, según hemos mencionado antes. El doctoral afirmaba directamente: "hoy contra la institución de la Iglesia ha vuelto la tibieza de los últimos siglos una señal de honor y distinción". Como en principio no debía ser tal, no debía ser sólo un honor, el canónigo no veía (de nuevo, en principio) obstáculo en que se concediera no sólo al ayuntamiento sino incluso al pueblo. El problema estaba en que se pidiera al mismo tiempo y de la misma forma en que se daba al Cabildo Catedral, el problema era que no se podían igualar las corporaciones de distinto rango: "repugna esta pretendida igualdad a la significación de la ceremonia, a lo prescripto en el particular por los sagrados ritos y a la desigual representación de ambos cabildos", sentenció el doctor De los Ríos. ${ }^{73}$

Para el lector contemporáneo puede parecer paradójico, mas el doctoral reconocía que en sus orígenes el beso de la paz no era una distinción particular sino un acto de todos los fieles, idealizaba esos remotos tiempos e incluso concedía que no debía ser otro el principio fundamental del rito. Empero, de inmediato se trazaba la frontera entre el clero y el pueblo, que convertía al beso de la paz en expresión de la jerarquía de la Iglesia. Es en ese sentido que hablaba de la significación de la ceremonia: "Dase la paz en señal de unión y hermandad en Cristo, y como de los hermanos sean sin duda en la Iglesia los primeros y mayores los eclesiásticos, no puede pretender igualárseles en el tiempo y modo de recibir la paz". ${ }^{74}$ En fin, la jerarquía la ordenaban las autoridades en materia de liturgia, que el canónigo citaba varias veces, y que no eran sino la Santa Sede, a través de los libros litúrgicos, en particular el Ceremonial de los Obispos, y la Congregación de Ritos, y los diversos autores comentaristas de dichas obras.

Acaso lo más duro del dictamen es el esfuerzo del doctoral en dejar claro el punto de la "desigual representación" de las corporaciones, que llegaba hasta menospreciar los méritos de la ciudad de Valladolid. Ante todo, el dictamen dejaba en claro una idea que acaso compartían los canónigos de otras catedrales: el Cabildo Catedral era la representación del clero y de la dignidad episcopal, mientras que el Ayuntamiento no era sino la representación del pueblo de una ciudad; el portapaz únicamente hubiera podido compartirse con la representación de la Majestad del rey, y ya hemos visto que incluso en ese caso era difícil que se le concediera a cualquier magistrado real. ${ }^{75}$ Pero el doctoral De los Ríos iba más allá: para él también, como para los fiscales

del Cabildo Catedral de Valladolid de Michoacán de 5 de octubre de 1772, fs. 5-58.

${ }^{73}$ Ibídem, testimonio adjunto a la representación del Cabildo Catedral de Valladolid de Michoacán de 5 de octubre de 1772, informe del canónigo doctoral, Valladolid, 17 de octubre de 1770, fs. 30-58. E tema de la "igualdad ceremonial" también llegó a suscitarse en Puebla, pero a propósito del uso de sillas: Ramos, F.L. 2010: 275-276.

74 Ídem

75 Ídem.
Lanz Casafonda y el Marqués de Aranda, el portapaz era, por lo que tocaba a los ayuntamientos, un privilegio exclusivo de los de México y Lima. Por ello, abundaba en los motivos por los que Valladolid no podía llegar a compararse con ninguna de esas ciudades, siendo que los munícipes habían fundado su solicitud en los méritos de su ciudad. ${ }^{76}$

En marzo de 1788, el ayuntamiento de Guadalajara formuló su petición de participar del portapaz en términos muy semejantes. Si el de Valladolid alegaba ser de las ciudades "más principales y ennoblecidas del reino" en 1772, Guadalajara podía citar su condición de "capital de reino", "Corte tan antigua", residencia de "la viva imagen" del rey en su Real Audiencia, "una antigua silla episcopal", e incluso "un comercio floreciente"77. Ambos ayuntamientos coincidieron además en dos puntos, primero, en que eran los honores, el de la paz incluido por supuesto, los que constituían la retribución más importante para los miembros de las corporaciones municipales. Los munícipes de Valladolid como los de Guadalajara insistieron en que la falta de prerrogativas en las ceremonias podía incluso ocasionar el abandono de las regidurías, lo que perjudicaría a los habitantes de la cuidad. En ese sentido, podría decirse que, mientras los honores de los jueces reales podían justificarse sobre todo alegando la representación del Patronato, en el caso de los ayuntamientos se trataba sobre todo de considerar la participación de la paz como un asunto de utilidad pública, o mejor dicho, utilidad del público, entendido como el conjunto de los miembros de la comunidad urbana.

En segundo lugar, es importante notar que los expedientes de ambos ayuntamientos cuestionaron la exclusividad del privilegio que las Leyes de Indias concedían sólo a las ciudades de México y Lima evocando otros ejemplos ${ }^{78}$. Esto es, entre los argumentos que alegaban uno era que la paz se concedía ya a otros ayuntamientos de los reinos de Indias y en particular de Nueva España, como sucedía en efecto. El ayuntamiento de Guadalajara señaló al menos otros tres casos novohispanos: Zacatecas, Guanajuato y León, destacando además el de la ciudad de Manila, donde, afirmaba, se daba la paz al ayuntamiento "por un capellán con sobrepelliz" en la Catedral y en las otras iglesias directamente por el subdiácono. ${ }^{79}$

En el expediente de Valladolid, fue José Antonio Areche, fiscal de la Real Audiencia de México, quien apuntó más extensamente esos otros casos en su pedimento de 4 de mayo de 1771, elaborado sobre todo en respuesta al doctoral De los Ríos que hemos citado antes. Según el fiscal, la paz se daba "a los cabildos de Pátzcuaro, Querétaro, San Luis Potosí, Celaya, Salvatierra, Guanajuato, Veracruz, Orizaba y

76 Los argumentos vallisoletanos aparecen transcritos en la real provisión de 10 de septiembre de 1770 dirigida al Cabildo Catedral de Valladolid en ibídem, testimonio adjunto a la representación del Cabildo Catedral de Valladolid de Michoacán de 5 de octubre de 1772, fs. 1-4v e ibídem, representación del Ayuntamiento de Valladolid, Madrid, 21 de febrero de 1772.

77 AGI, Guadalajara, leg. 379, representación del Ayuntamiento de Guadalajara, 14 de marzo de 1788.

78 Ya hemos visto que en el siglo XVII se usaba el mismo argumento en los reinos de América del Sur.

79 AGI, Guadalajara, leg. 379, representación del Ayuntamiento de Guadalajara, 14 de marzo de 1788 . 
Guadalajara", 80 por lo que tenían razón los munícipes vallisoletanos en que se le negaban "honores que son debidos y regulares a semejantes cuerpos". La postura de Areche era de las más originales entre todos los actores de estas querellas, pues si bien no llegó a cuestionar directamente la jerarquías en la Iglesia, fue acaso el único en insistir en llevar a sus últimas consecuencias la recuperación de los orígenes del rito que había descrito el doctoral De los Ríos. Como el canónigo, afirmaba que "una mala inteligencia ha hecho disputables las ceremonias eclesiásticas que se repartían francamente a los fieles católicos"; sin embargo, frente a la extensa defensa del doctoral, se pronunciaba por una solución sencilla en extremo para solucionar el problema principal, el de la representación de uno y otro cuerpo: dar la paz por "persona más o menos condecorada" para significar los distintos rangos. ${ }^{81}$

El dato principal que nos ofrece el fiscal, es que, contrario a Puebla, Valladolid y Guadalajara, los ayuntamientos de otras ciudades y villas, donde no había obispos ni canónigos, accedían con cierta facilidad al rito de la paz. Vale la pena volver sobre algunos de ellos, en particular los de León y Orizaba, de los que contamos con más información. Sobre el caso orizabeño, las querellas por la paz fueron parte de las disputas entre la república de indios y el ayuntamiento de españoles que marcaron la política local durante el último tercio del siglo XVIII y primeros años del XIX ${ }^{82}$ Lo primero que sorprende en el contexto que aquí hemos venido esbozando es la facilidad con que las autoridades civiles orizabeñas obtuvieron el privilegio del portapaz, no sabemos exactamente desde qué fecha, pues el tema de su disputa no era obtenerlo sino el orden en que se les habría de conceder y la calidad del ministro portapaz. Según un informe del propio ayuntamiento, fundaron su privilegio en los honores que disfrutaban los munícipes de la vecina villa de Córdoba. ${ }^{83}$ Empero, esto no significa que los párrocos de Orizaba tuvieran una opinión radicalmente distinta sobre la concesión del portapaz respecto de los canónigos de la época, si bien no contamos con sus respuestas por extenso, de su conducta se puede inferir que estimaban también que la paz debía distinguir la representación de la república de españoles por encima de la de indios.

Los indios de Orizaba acudieron a la Real Audiencia de México en 1769 , solicitando los mismos honores que el

80 AGI, México, leg. 2662, “Testimonio del expediente formado a representación del Cabildo eclesiástico de Valladolid sobre que el alcalde mayor le dé el tratamiento de señoría y recursos introducidos por el secular acerca de que en las funciones de Iglesia se le dé la paz y otros honores", fs. 33-34. Evidentemente el fiscal exageraba al incluir al Ayuntamiento de Guadalajara, que como acabamos de mencionar, solicitó el acceso al portapaz hasta 1788.

81 Ídem.

82 Al respecto nos permitimos remitir a la tesis Carbajal López, D. 2010 Utilité du public ou cause publique. Les corporations religieuses et les changements politiques à Orizaba (Mexique), 1700-1834: 123-129. Paris : Université Paris I Panthéon-Sorbonne, thèse pour obtenir le grade de Docteur en Histoire. Asimismo, Cruz Soto, I. G. 1996 “Querellas de cabildos en la 'Garganta del Reino': indios y españoles en Orizaba al final de la Colonia", La palabra y el hombre, 99: 37-71.

83 AGI, México, leg. 1283, "Testimonio del expediente formado a pedimento del cabildo de villa de León sobre que se le guarden los mismos honores que a la villa de Lagos y otros privilegios como adentro se expresa", fs. 15-16v, informe del Ayuntamiento de Orizaba, 15 de septiembre de 1783. ayuntamiento de españoles tenía en la iglesia parroquial. Lo interesante de su solicitud es que la fundaron en un mérito muy concreto: eran ellos quienes la habían fabricado y quienes la servían; años más tarde, en 1774 , cuando llevaron sus quejas ante el rey en el Consejo de Indias, fueron un paso más lejos: como ellos la habían construido y dotado, por tanto "se les debe atribuir el glorioso nombre de Patronos de su iglesia". ${ }^{44}$ El caso es interesante también, porque le tocó examinarlo al ya citado fiscal Areche, quien en su respuesta de 13 de septiembre de 1769 le dio un giro distinto al rito de la paz. No lo estimó tanto como una ceremonia sagrada ni como un elemento que debía regirse estrictamente por la costumbre -antes bien reconoció que no la había de dar el portapaz a los indios-, sino de manera directa como un honor que podía estimular a los indios: "inclinándolos a que apeteciesen y solicitasen mejor fortuna y menos infeliz estado de aquel en que les tiene su inacción y miseria". 85 Fue así como después de otras largas diligencias, en auto de 23 de noviembre de 1772 el Real Acuerdo de México ordenó que recibieran la paz justo después de los españoles y justo como ellos (por tanto, de manos del mismo ministro). ${ }^{86}$

Para contrarrestar esta decisión, parece ser que el ayuntamiento de españoles logró del párroco un privilegio que ya hemos visto disputar sin éxito a sus homólogos de las ciudades episcopales, la concesión de la paz al mismo tiempo que el clero y por un clérigo sacristán, dejando la paz de los indios en manos de un monaguillo. Esto generó, desde luego, nuevas contestaciones ante la Real Audiencia, que en marzo de 1773 insistía en ordenarle al párroco de Orizaba cumpliera con lo que se había resuelto el año anterior. Mas el maestro Francisco Antonio Illueca respondió alegando la "notable incomodidad" que resultaba para las ceremonias eclesiásticas darle la paz al cabildo de naturales por el mismo ministro que la daba a los munícipes españoles. ${ }^{87} \mathrm{Si}$ el párroco orizabeño llegaba a estimar como "indecente" que un eclesiástico saliera a recibir o despedir a la república de indios, su homólogo de León, don Juan José Moreno, se negaba por su parte a darle la paz al ayuntamiento español de esa villa en 1783 , fundado tanto en que no había costumbre al respecto como porque lo estimaba una práctica que se hacía con ciudades y no con villas. ${ }^{88}$ Uno se preocupaba porque se pudieran igualar españoles e indios y el otro ciudades y villas, pero en cualquiera de los dos casos, se diría que no sólo los canónigos, sino también el clero parroquial, era reticente a cualquier modificación en el ceremonial que pudiera mostrar cambios en las jerarquías sociales.

84 AGI, México, leg. 1770, testimonio de la real provisión de la Real Audiencia de México de 5 de diciembre de 1772 y AGI, México, leg. 1766 , representación del cabildo de naturales de Orizaba, Madrid, 20 de diciembre de 1774.

85 AGI, México, leg. 1770, testimonio de la real provisión de la Real Audiencia de México de 5 de diciembre de 1772.

86 Ídem.

87 Ibídem, testimonio de la real provisión de la Real Audiencia de México de 8 de julio de 1773.

88 Paradójicamente el párroco se equivocaba: era un rito que se practicaba más con las villas que con las ciudades. AGI, México, leg. 1283, "Testimonio del expediente formado a pedimento del cabildo de villa de León sobre que se le guarden los mismos honores que a la villa de Lagos y otros privilegios como adentro se expresa", fs. 5-6, Juan José Moreno al Ayuntamiento, León, 12 de abril de 1783. 
El ayuntamiento de León, de manera semejante al de españoles de Orizaba, trató de fundar su derecho al portapaz en la costumbre establecida en una villa vecina, la de Santa María de los Lagos. Allí, según certificó el escribano de cabildo en el mismo año 1783, "en todas las funciones se comunica la paz a las personas que componen el ilustre cuerpo al mismo tiempo que a los señores eclesiásticos por medio de un monacillo con opa y sobrepelliz". ${ }^{89}$ Mientras corporaciones municipales que alegaban su nobleza y méritos en ciudades episcopales no pudieron vencer la resistencia de obispos y canónigos para obtener el portapaz, los ayuntamientos de las villas lo habían alcanzado desde tiempo atrás, como en Córdoba y en Lagos, o contaban con la anuencia del Consejo de Indias para alcanzarlo a partir del ejemplo de sus vecinos, como Orizaba y León, hasta el punto que el cabildo de indios de Orizaba recibía la paz por real cédula, pero no el ayuntamiento de Puebla de los Ángeles (sólo su presidente, como hemos visto antes), en una negativa confirmada asimismo por cédula real. ${ }^{90}$ El privilegio pues no era sólo de México y Lima como se establecía en las Leyes de Indias, ni tampoco se hallaba extendido a todas las corporaciones municipales, sino sólo a aquellas que habían probado que les beneficiaba la costumbre o, como en el caso de los indios de Orizaba, que pudieron alegar ni más ni menos el patronato y por tanto cierta tutela sobre su iglesia parroquial.

\section{COMENTARIOS FINALES}

El beso de la paz, lo reconocían los propios actores de las querellas que hemos revisado, tenía orígenes remotos en la historia del Cristianismo, pero se había transformado de manera sustancial en tiempos de la Reforma católica en el siglo XVI. A partir de entonces se había convertido en un rito que marcaba las jerarquías propias de la Iglesia católica, entre el clero y el pueblo, entre el soberano, los magistrados y los súbditos. Si la liturgia trataba así de proteger el acceso a lo sagrado, al mismo tiempo convertía al portapaz en tema de querellas, en las cuales, según hemos visto, los argumentos para tener acceso a este privilegio dejaban poco a poco los marcos exclusivamente religiosos. Además, el ritual de la paz se volvía un terreno en que se probaba el predominio de autoridades civiles o eclesiásticas en el mundo urbano del siglo XVIII hispánico.

En efecto, sólo los obispos y canónigos se esforzaban en proteger el portapaz fundándose en libros litúrgicos, en las decisiones de las congregaciones romanas y en el derecho canónico. La ley, sus comentaristas, la costumbre y el patronato regio eran los otros argumentos tradicionales para alcanzar el anhelado beso del portapaz, oportunamente alegados por los magistrados y fiscales, pero también por los propios eclesiásticos, normalmente en sentido negativo. Cabe destacarlo, incluso clérigos regalistas, como el obispo Francisco Fabián y Fuero, no fueron meros instrumentos de una política de la Corona, sino también defensores firmes de la sacralidad del ritual y de la jerarquía del clero.

\footnotetext{
89 Ibídem, "Testimonio del expediente formado...", fs. 4-4v.

90 AGI, México, leg. 2662, real cédula de 21 de julio de 1770.
}

Frente al clero y a los magistrados reales, la mayor originalidad de los argumentos presentados en estas querellas estuvo sin duda en los reclamos de los ayuntamientos y los dictámenes del fiscal Areche, en que se recurría a argumentos fundados en el honor y méritos de las ciudades y villas, y que si bien podían estar asociados a la protección del culto parroquial (como fue con los indios de Orizaba), no eran exclusivamente méritos religiosos. Con el fiscal Areche en particular, hemos visto que era posible ya un tímido cuestionamiento de las jerarquías en materia del culto religioso, sensibilidad propia de los reformadores de la época que también se expresó en otros casos, como en la reforma de cofradías, cuestionando que rituales en principio propios de la devoción se convirtieran en expresiones de la vanidad. ${ }^{91}$

Desde luego, lo más notable en estas querellas es que nos muestran que en tiempos de las Reformas borbónicas, el poder se seguía disputando en las ceremonias eclesiásticas. Más todavía, si bien una historiografía ya extensa ha abundado en el tema del debilitamiento de las autoridades eclesiásticas ante los magistrados civiles, en virtud de las reformas impulsadas por los ministros de la Corona, ${ }^{92}$ estas querellas son muestra de que los obispos y canónigos podían defenderse bien en el terreno fundamental de los rituales. Además, nos muestran que si la Corona tuvo un papel fundamental en la resolución de estas querellas, es claro que nunca hubo de parte suya una definición clara sobre quiénes debían tener acceso a este privilegio, ni siquiera cuando se trataba de los propios magistrados reales creados por las Reformas borbónicas ${ }^{93}$.

Sobre este último punto podemos confirmarlo en el caso de los intendentes, acaso los más importantes magistrados creados por las reformas y quienes tenían a su cargo implementarlas a nivel regional: lo hemos señalado en otros casos, en el reino del Perú, el visitador Jorge Escobedo intentó redactar un ceremonial para los intendentes que les reconociera su carácter de vicepatronos al mismo tiempo que su subordinación al virrey. Desde luego, les concedió la paz, de manos de un clérigo y no del diácono o del subdiácono, en los mismos términos que los presidentes de Audiencia y gobernadores; es decir, al mismo tiempo que el obispo si estaba en el coro, y después de él si se encontraba en la capilla mayor. El Consejo de Indias en pleno rechazó dicho ceremonial en 1790, y terminó validando las costumbres locales. No fue sino en la Ordenanza de Intendentes de 1803 que apareció por fin una regla uniforme para su tratamiento en las iglesias, pero limitada al tema del asiento que debía dárseles. ${ }^{94}$

91 Nos permitimos citar: Carbajal López, D. 2012 “La reforma de las cofradías novohispanas ante el Consejo de Indias, 1767-1820", Revista complutense de Historia de América. 38:79-101 en particular 95-96.

92 Véase sobre todo la obra clásica de Brading, D. 1994. Una Iglesia asediada: el obispado de Michoacán, 1749-1810. México: Fondo de Cultura Económica.

93 Empero, el trabajo de Ramos, F.L. 2010:11-14 es interesante porque muestra los honores concedidos a los militares frente al Ayuntamiento de Puebla, incluyendo la banca forrada en la Catedral.

94 La Ordenanza la hemos consultado en: Zamora, J.M. 1839 Registro de legislación ultramarina y ordenanzas de intendentes de 1803 con adición de todas las reales disposiciones que la son referentes:148-149. La Habana: Imprenta del gobierno y capitanía general. 
En fin, conviene advertir que este es apenas un esbozo que intenta mostrar el interés que ofrece tanto para la historia religiosa como para la historia política el abordar el tema de las ceremonias eclesiásticas construidas por la Reforma católica en tiempos de las Reformas borbónicas. Hecho mayormente a partir de fuentes de nivel imperial y con una mirada a escala del reino de Nueva España, debe ser completado, sin duda, con investigaciones en fuentes locales que permitan ahondar en el tema de la relación entre los ayuntamientos y el clero parroquial, y por supuesto, con datos comparativos para otros territorios del mundo hispánico.

\section{REFERENCIAS Y BIBLIOGRAFÍA}

\section{Archivos}

AGI Archivo General de Indias.

\section{Fuentes impresas}

Bauldry, M. 1703 Manuale Sacrarum Caeremoniarum, juxta ritum S. Romanae Ecclesiae. Venecia: Paulum Balleonium.

Benedicto XIV. 1827 Caeremoniale episcoporum. Nápoles: Typographia Simoniana.

Covarrubias, J. 1783 Máximas sobre recursos de fuerza y protección con el método de introducirlos en los tribunales. Madrid: Imprenta de la viuda de Ibarra.

De Olalla y Aragón, F. B. 1696 Ceremonial de las misas solemnes cantadas con diáconos o sin ellos, según las Rúbricas del Misal Romano, últimamente recognito por Su Santidad Urbano VIII. Madrid: Juan García Infanzón impresor.

Durand, G. 1854, Rational ou Manuel des Divins offices. Paris: Louis Vivès.

Gavanto, B. 1763 Thesaurus Sacrorum Rituum. Augusburgo: Matthei Rieger.

Murillo Velarde, P. 2005 Curso de derecho canónico hispano e indiano. Zamora, El Colegio de Michoacán/UNAMFacultad de Derecho.

Rivadeneyra, A.J. 1755 Manual compendio del Regio Patronato Indiano. Madrid: Antonio Marín.

Villarroel, G. 1703 Gobierno eclesiástico-pacífico y unión de los dos cuchillos pontificio y regio. Madrid: Antonio Marín.

Zamora, J.M. 1839 Registro de legislación ultramarina y ordenanzas de intendentes de 1803 con adición de todas las reales disposiciones que la son referentes:148-149. La Habana: Imprenta del gobierno y capitanía general.

\section{Bibliografía}

Bossy, J. 1981. "Essai de sociographie de la messe, 12001700". Annales. Économies, Sociétés, Civilisations 36-1: 44-70.
Bossy, J. 1983. "The mass as a social institution, 12001700". Past and present 100: 29-61.

Brading, D. 1975 Mineros y comerciantes en el México borbónico (1763-1810). México: Fondo de Cultura Económica.

Brading, D. 1991 “La España de los Borbones y su Imperio Americano", en L. Bethell (ed.), Historia de América Latina, vol. 2: "América Latina Colonial: Europa y América en los siglos XVI, XVII, XVIII": 85-126. Barcelona: Crítica / Cambridge University Press.

Brading, D. 1994. Una Iglesia asediada: el obispado de Michoacán, 1749-1810. México: Fondo de Cultura Económica.

Bravo Arriaga, M. D. 1998 "El otro rostro de Jano: Rituales y celebraciones en honor del 'Más claro Sol de las Españas', Felipe IV, 1666" en H. Pérez Martínez (ed.), México en fiesta: 329-337. Zamora: El Colegio de Michoacán.

Buckholder, M. A. y D. S. Chadler 1984 De la impotencia a la autoridad. La Corona española y las Audiencias en América, 1687-1808. México: Fondo de Cultura Económica.

Cabantous, A. 2004. Entre fêtes et clochers. Profane et sacré dans I'Europe moderne, XVII ${ }^{e}-\mathrm{XVIII}{ }^{e}$ siècle. Paris: Fayard.

Cañeque, A. 2004 "De sillas y almohadones o de la naturaleza ritual del poder en la Nueva España de los siglos XVI y XVII". Revista de Indias 232: 609-634.

Carbajal López, D. 2010 Utilité du public ou cause publique. Les corporations religieuses et les changements politiques à Orizaba (Mexique), 1700-1834. Paris: Université Paris I Panthéon-Sorbonne, tesis para obtener el grado de Doctor en Historia.

Carbajal López, D. 2012 "La reforma de las cofradías novohispanas ante el Consejo de Indias, 1767-1820", Revista complutense de Historia de América. 38:79-101.

Cruz Soto, I. G. 1996 "Querellas de cabildos en la 'Garganta del Reino': indios y españoles en Orizaba al final de la Colonia", La palabra y el hombre, 99: 37-71.

De la Hera, A. 1992 Iglesia y Corona en la América española. Madrid: Mapfre.

Duve, T. 2010. "Catequesis y derecho canónico entre el Viejo y el Nuevo Mundo" en R. Schmidt-Riese (ed.), Catequesis y derecho en la América colonial. Fronteras borrosas: 131-145. Madrid: Iberoamericana-Vervuert.

Koslofsky, C. 2005 "The kiss of peace in the German Reformation", en Karen Harvey (ed.), The Kiss in History: 19-35. Manchester: Manchester University Press.

Lempérière, A. 1998. "República y publicidad a finales del Antiguo Régimen (Nueva España)" en F.-X. Guerra y A. Lempérière (coords.), Los espacios públicos en Iberoamérica. Ambigüedades y problemas. Siglos XVIII-XIX: 54-79. México: Fondo de Cultura Económica/ Centro Francés de Estudios Mexicanos y Centroamericanos.

Lempérière, A. 2004 Entre Dieu et le roi: La république. Mexico, $X V I^{e}-X I X^{e}$ siècles: 150-156. París: Les Belles Lettres.

Liehr, R. 1976 Ayuntamiento y oligarquía en Puebla, 1787-1810: 123. México: Secretaría de Educación Pública. 
Martin, P. 2010 Le théâtre divin. Une histoire de la messe, $X V I^{e}-X X^{e}$ siècle: $10-18$. París: CNRS Editions.

Mínguez, V. 1995 Los reyes distantes. Imágenes del poder en el México virreinal. Castelló de la Plana: Universitat Jaume I.

Pietschmann, H. 1996 Las reformas borbónicas y el sistema de intendencias en Nueva España. Un estudio político administrativo. México: Fondo de Cultura Económica.

Prodi, P. 2010. El soberano pontífice. Un cuerpo y dos almas: La monarquía papal en la primera Edad Moderna: 225-268 Madrid: Akal.

Ramos, F. L. 2010 “Creando sujetos reales a través de las Reformas Borbónicas: La corona, el cabildo y la manipulación de la ceremonia de la 'segunda ciudad' del reino", en XIII Reunión de historiadores de México, Estados Unidos y Canadá: 3. Querétaro, versión digital http://13mexeuacan.colmex.mx/ Ponencias\%20PDF/Frances\%20Lourdes\%20Ramos.pdf.
Ramos, F. L. 2010 "Negociar el poder y reafirmar la fe en la Puebla del siglo XVIII. Los cabildos y la solución de los conflictos en el ámbito ceremonial", en F. J. Cervantes Bello (coord.), La Iglesia en la Nueva España: relaciones económicas e interacciones políticas: 257-289, en particular 274-275 Puebla: Benemérita Universidad Autónoma de Puebla.

Sánchez de Tagle, E. 2010. "Las reformas del siglo XVIII al gobierno; la ciudad, su hacienda, su policía, su ejército" en C. García Ayluardo (coord.), Las reformas borbónicas, 1750 1808: 164-224. México: CIDE/ Fondo de Cultura Económica/ Conaculta / INEHRM/ Fundación Cultural de la Ciudad de México.

Valenzuela, J. 2001 Las liturgias del poder: celebraciones públicas y estrategias persuasivas en Chile colonial (16091709). Santiago de Chile: Centro de Investigaciones Diego Barrios Arana/ Ediciones Lom. 